\title{
Safranbolu Yörük Köyü ve Yakın Çevresinin Ekoturizm Potansiyelinin R'WOT Analizi ile Değerlendirilmesi
}

\author{
Yasin Dönmez ${ }^{a *}$, Ercan Gökyer ${ }^{b}$, Feride Kübra Aşkınc \\ ${ }^{a}$ Karabük Üniversitesi, Orman Fakültesi, Karabük. \\ ${ }^{b}$ Bartın Üniversitesi, Orman Fakültesi, Bartın. \\ cBartın Üniversitesi, Fen Bilimleri Enstitüsü, Bartın.
}

\begin{abstract}
$\ddot{O} z$
2000'li yıllardan sonra büyük ölçüde önem kazanan ekoturizm faaliyetleri özellikle son yıllarda, doğal ve kültürel özellikleri büyük ölçüde korunmuş kırsal alanlarda rağbet görmeye başlamıştır. Ekoturizm; doğaya dayalı turizm faaliyetleri gerçekleştirilirken, aynı zamanda doğal çevreyi korumayı ve halka ekonomik ve sosyal açıdan fayda să̆lamayı hedeflediği için kırsal kalkınmada etkili bir araç olarak görülmektedir. Bu çalışmada Kültür ve Turizm Bakanlığ tarafından koruma altına alınan, UNESCO Dünya Miras Kenti Safranbolu'ya bağlı Yörük köyü ve yakın çevresi ele alınmıştır. Çalışmada ilk olarak yerinde gözlem ve anket çalışmaları ile mevcut durum saptanmış sonrasında ise R'WOT analizi yapılmıştır. Çalışmada ayrıca Yörük Köyü ve yakın çevresinde ekoturizm olanakları ve ekoturizmin kırsal kalkınmadaki önemi tartışılarak, öneriler geliştirilmiştir.
\end{abstract}

Anahtar Kelimeler: Ekoturizm, kırsal kalkınma, kültürel miras, Safranbolu, Yörük Köyü.

\section{Assessment of Ecotourism Potential of Safranbolu Yörük Village and its Surroundings by R'WOT Analysis}

\begin{abstract}
Ecotourism has gained great importance after 2000s, especially in the rural areas where natural and cultural assets have been protected. Eco-tourism has seen as an efficient tool for rural development as it aims to protect natural environment and provide economic and social benefits to the local community while performing nature-based activities. In this study Yörük, a protected area of the Ministry of Culture and Tourism and a village of Safranbolu which is a UNESCO World Heritage city and its surroundings are examined. In order to determine the current situation of the village at first, observations and empirical survey then $R^{\prime} W O T$ analysis were carried out. In this paper ecotourism opportunities in Yörük village and its surrounding and the importance of rural development are discussed. Besides in order to develop ecotourism in the area some recommendations are presented.
\end{abstract}

Keywords: Ecotourism, rural development, cultural heritage, Safranbolu, Yörük Village.

\section{Giriş}

Ekoturizm fikri insanların doğaya karşı olan merak ve ilgilerinin birleşmesi sonucu ortaya çıkmıştır (Benzer, 2006). Ekoturizm kavramı ilk olarak 1983 yılında tanımlanmasına rağmen kavramın gelişmesi ve kamuoyu tarafından öneminin kavranması 2000'li yıllarda hız kazanmıştır (Türker, 2013). Birleşmiş Milletler (BM) 
tarafından 2002 yılının ekoturizm yılı olarak ilan edilmesiyle ekoturizm kavramının uluslararası anlamda önemi ve gerekliliği resmen kabul edilmiştir.

"Ekolojik turizm" yani "ekoturizm" ile ilgili çalışmalar incelendiğinde, ekoturizmin doğaya dayalı turizmin bir alt kategorisi olduğu görülmektedir. Turoğlu ve Özdemir (2005)’e göre ekoturizm; doğal ve kültürel miras konulu, ziyaretçi ve yerel halkın menfaatlerini gözeten, korumacı ve eğitsel, sürdürülebilir turizm faaliyetleridir.

Ekoturizmin belli hedefleri vardır. Bu hedefleri şu şekilde sıralamak mümkündür (Turoğlu ve Özdemir, 2005);

- Doğal ve kültürel mirasın korunmasına aktif olarak katkıda bulunmak,

- Halkın refah seviyesini yükseltmek,

- Yörenin doğal ve kültürel mirasını turistlere tanitmak,

- Gruplara olduğu kadar, bireysel turistlere de en iyi imkânları sunmak,

- Geri kazanılması mümkün olmayan kaynak kayıplarını en aza indirmek,

- Turizm yönetimi ve ilgili organizasyonlarda yerel halkın katılımcı rol alması,

- Turiste tanitma-bilgilendirme, yerel halka ise kültürel, sosyal ve ekonomik gelişme hizmeti getirmek,

- Turistlerin olduğu kadar yerel halkın da sürdürülebilir turizm konusunda bilinçlenmelerini sağlamak,

- Ekoturizm faaliyetlerindeki iş imkânlarını tekelcilikten kurtarıp, geliri yerel halk ile ilgili kurum ve kuruluşlara eşit olarak yayarak dağıtmak,

- Turizm faaliyetlerinin her anlamdaki olumsuz etkilerini en aza indirmek

Ekoturizm doğayı anlama ve doğadan zevk almanın yanı sıra, kırsal kalkınmayı desteklerken doğal çevreyi koruyacak eylemlerde bulunmayı da gerektirmektedir. Bu yönüyle ekoturizmin doğal ve kültürel zenginliklere sahip gelişmekte olan ülkelerdeki kırsal alanlar için önemli bir sürdürülebilir gelir kaynağ1 olduğu söylenebilir (Türker, 2013).

Kırsal alanların sahip olduğu peyzaj özellikleri, yerel yaşam biçimleri ve özgünlükleri ile sosyal yaşamda başlıca dört önemli işlevi bulunmaktadır (Kiper, 2006);

(1) Gida üretim yerleridir,

(2) Köy el sanatları ve endüstri için zemin oluştururlar,

(3) Tarım ve diğer ekonomik dallarda faaliyet gösteren halkın yerleşme alanlarıdır,

(4) Kentler ve endüstri yerleşmelerindeki halk için dinlenme yerleridir.

Kırsal kalkınma, genel anlamıyla yöre halkının kırsal alandaki yaşam koşullarını iyileştirmeye, yönelik ekonomik ve sosyal politikalar bütünüdür (Cengiz, 2003). Ekoturizmin temelinde doğal değerleri koruyarak geliştirmek yer aldığı için kırsal alanların kalkınmasında en önemli araçlardan biri olarak görülmektedir.

Ekoturizm faaliyetlerini gerçekleştiren kişilere ekoturist denilmektedir. Ekoturistler daha doğal bir çevreyle ilgilenmekte ve zorlu deneyimler sunan, insanlardan uzak yerleri tercih etmektedirler (Pedersen, 2002). 
Ekoturistler için önemli çekim öğeleri; bakir ve el değmemiş alanlar, Milli parklar ve koruma alanları, kırsal alanlar, dağlık alanlar, göl ve nehirler, tarihi alanlar ve sit alanları, kültürel aktivitelerin yapıldığı alanlar, okyanus ve deniz kenarları olarak belirtilebilir (Benzer, 2006).

Ekoturistlerin bu alanlara seyahat etme nedenleri ve amaçları arasında; doğa ve kırsal yaşamla etkileşim, sosyal etkileşim, bilme, tanıma, keşfetme, eğitim, bilimsel merak, bilgilenme, risk arayışı, kendini keşfetme ve kendini gerçekleştirme olarak gösterilebilir (Altan, 2006). Ekoturizm kapsamında kabul edilen bazı aktiviteler-turizm çeşitleri (Benzer, 2006); kuş ve yaban hayatı gözlemciliği, foto safari, trekking, dağcılık, yamaç paraşütü kamp karavan turizmi, yayla turizmidir. Bu çalışmada Safranbolu Yörük Köyü ve yakın çevresi çalışma alanı olarak seçilmiştir.

Çalışma alanı olarak Safranbolu-Yörük köyü' nün seçilmesinde;

- İlgi çekici doğal ve kültürel peyzaj özelliklerine sahip olması,

- UNESCO Dünya Miras Listesinde yer alan Safranbolu ilçesinin bir köyü olması,

- Kültür ve Turizm Bakanlığı tarafından 1997 yılında koruma altına alınarak, tarihi kültürel ve geleneksel dokusunu günümüze kadar koruyan bir yerleşim yeri olması etkili olmuştur.

Çalışmanın amacı Safranbolu'ya bağlı Yörük Köyü ve yakın çevresindeki ekoturizm olanaklarının potansiyelini R'WOT analizi kullanarak saptamak, köyün kırsal kalkınmasına katkısını tartışmaktır.

\section{Literatür}

Yılmaz (2006) tarafından yapılan "R'WOT Tekniği; Arıcılık Sektöründe Katılımcı Yaklaşım ile Örnek Bir Uygulaması" isimli çalışmasında, SWOT (Üstünlükler, Zayıflıklar, Fırsatlar/Olanaklar ve Tehditler/Tehlikeler) Çözümlemeleri uygulamalarının faydalanılabilirliğini, uygulanabilirliğini, etkinliğini ve yeteneğini arttırma amacıyla, "R'WOT Tekniği" olarak adlandırılan melez bir teknik geliştirilmiştir. Bu kapsamda SWOT Çözümlemeleri ile Sıralama (Ranking) Tekniği ve Doğrusal Kombinasyon Tekniği bütünleştirilmiştir. R'WOT Tekniği vasıtasıyla, SWOT Çözümlemelerindeki SWOT grupları ve her bir SWOT grubu içerisindeki SWOT faktörlerine yönelik önem dereceleri, sayısallaştırılarak ölçülebilir hale getirilmiştir. Buna göre mevcut karar verme problemine yönelik izlenecek alternatif stratejiler acık bir şekilde ortaya konulmakta ve en uygun alternatif strateji seçilmesi amaçlanmaktadır.

Öztürk ve Tönük (2014) tarafından yapılan "Devrekani Çayı Havzası yönetim planı sürecine kamu kurumları ve özel sektör paydaşlarının katılımı" isimli çalışmada, suyun hayat verdiği doğa ve insan ile insanların beşeri faaliyetlerini kapsayan tüm bileşenler ele alınmaya çalışılmış, Devrekani Çayı Havzası ilgi gruplarından kamu kurumları ve özel sektörün katılımlarını sağlamak, görüş ve tutumlarını değerlendirmek amacıyla alanın güçlü ve zayıf yönleri, tehdit ve fırsatları (SWOT analizi) değerlendirilmiş R'WOT (Ranking+SWOT) Analizi ile önceliklendirilmiştir. Analiz sonucuna göre, her iki grup (kamu ve özel sektör), havza alanı için yapımı planlanan hidroelektrik santrallerin (HES) doğal kaynak değerlerini olumsuz etkileyeceğini belirtmişlerdir. 
Çalışma ile özellikle alana ilişkin tehditleri yüksek öncelikli tercih etmeyen, önemli karar verici mekanizmalarından birisini oluşturan kamu kurumları grubuna farkındalık oluşturulması öngörülmektedir.

\section{Yörük Köyü}

Araştırma alanı olan Yörük Köyü; Batı Karadeniz Bölümü'nde, Karabük İline bağlı olan Safranbolu İlçesi sınırları içindedir. Safranbolu, Karabük ilinin en büyük ve gelişmiş ilçesidir. $41^{\circ}-16^{\prime}$ kuzey enlemi ile $32^{\circ}-41^{\prime}$ doğu boylamında yer alır. Yörük köyü (Şekil 1), Safranbolu'nun doğusunda, Kastamonu yolu üzerinde 13. kilometrede yer almaktadır. Köyün güneyinden Araç Çayı geçmektedir.

Deniz seviyesinden yaklaşık olarak 600 m yükseklikte yer alan Yörük Köyü'nün kuzeyinde İnkayası 1544 m, Kırçaltepe 1165 m, Sarıçiçek Yaylası 1666 m, güneyinde ise Kuz Yakası 1113 m yükseltidedir. Köyün arazi yapısı hafif eğimlidir. İklim, Karadeniz iklimi ile İç Anadolu ikliminin karması olabilecek bir özellik göstermektedir. Yörede kışlar 1lık, yazlar ise sıcak geçmektedir. Türkiye İstatistik Kurumundan (TUIK) elde edinilen nüfus verilerine göre; 2012 yılında Yörük köyünde yaşayan nüfus 54'ü erkek, 64'ü kadın olmak üzere toplam 118 kişidir (TUIK 2012).

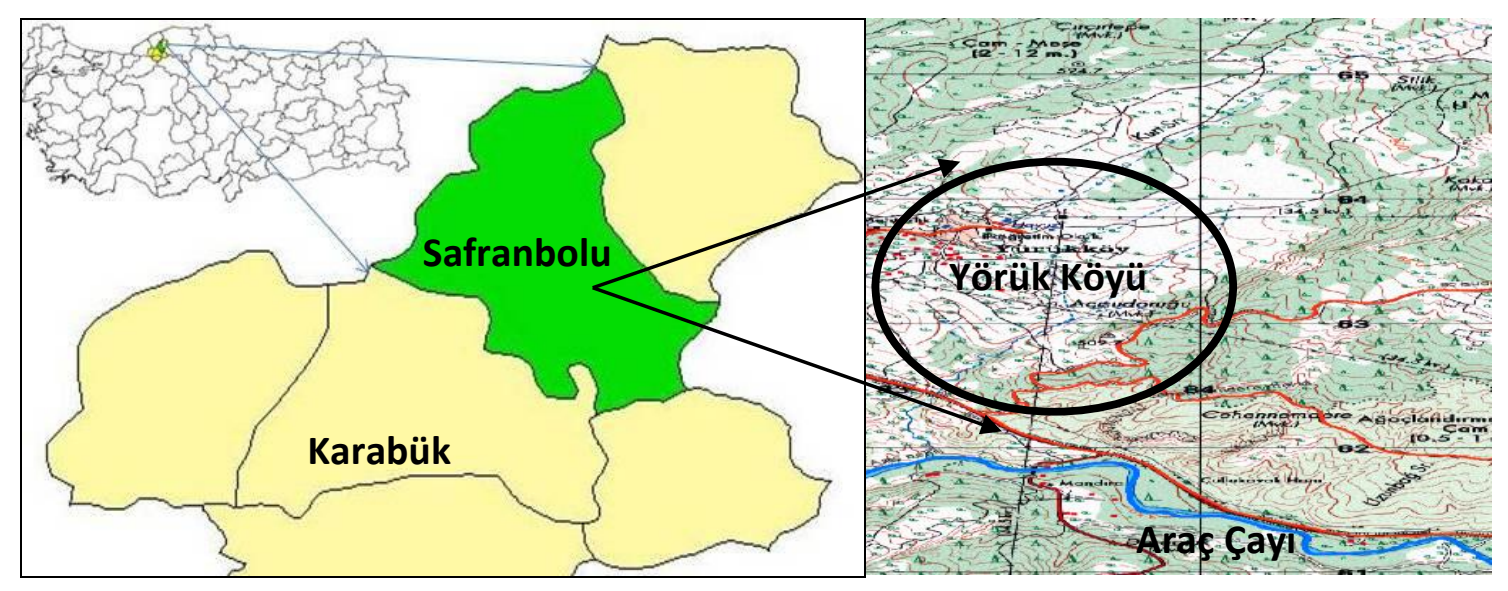

Şekil 1: Yörük köyü 'nün konumu

Yörük köyüne adını veren yörük kelimesi yürümek fiilinden türemiştir. Yörük sözcügüne Cengizhan'ın yasalarında da rastlanmaktadır ve vergi veren, sefere katılan, göç ve yerleşme hakkı tümüyle komutanlığa veya hükümdara ait asker anlamında kullanılmıştır. Doğuştan itibaren asker sayılan Yörükler, Türk töresinin korunmasında ve günümüze kadar yaşatılmasında büyük rol oynamışlardır (Kara, 2005).

Yörük Köyü'nde zamanında Bektaşi kültürüyle yaşanmıştır. Bektaşilik, 13. yüzyılın ortalarında Anadolu'da ortaya çıkmış, Osmanlılar tarafından resmi olarak tanınan bir tarikattır (Öztürk, 1996). Cumhuriyet sonrası köy halkının yaşamında Bektaşiliğin etkisi kalmamış; ancak Bektaşi ailelerin konutları bozulmadan günümüze dek kalabilmiştir (Demirarslan, 2011). Köyün çamaşırhanesinde ve evlerde Bektaşilik ile ilgili ince detaylara rastlamak mümkündür. Bu kültürün izlerini taşıması köyün, turistler için ilgi odağı olmasında önemli bir etkendir. 
Köy gerçek bir Türk-Türkmen köyü oluşu nedeniyle Kültür ve Turizm Bakanlığı tarafından 1997 yılında koruma altına alınmıştır. Yörük Köyü'nde koruma altına alınan tescilli yapılar: Cami, Çeşmeler, Konutlar, Mezarlık, Köy Odası, Hamam Kalıntısı, Misafirhane, Çamaşırhane olmak üzere toplam 131 tane eser bulunmaktadır. 250 yıllık olan Çamaşırhanenin ortasında bulunan büyük taş 12 köşeli olarak hazırlanmış olup Bektaşi kültürünü temsil etmektedir.

Yerel halk geçimini özellikle sebze ve meyve yetiştiriciliğinden sağlamaktadır. Önceden bağcllık köyde önemli bir yer tutarken bugün köyde eskisi kadar yapılamamaktadır. Yerel halka göre bunun sebebi, Karabük Demir Çelik Fabrikası'nın oluşturduğu çevre kirliliği nedeniyle üzüm bağlarına hastalık gelmesidir. Köyde 1 kişi safran bitkisi yetiştiriciliği yapmaktadır. Bunlara ek olarak köyde seracılık faaliyetleri, az da olsa hayvancılık yapılmaktadır. Köyde 3 tane gezi evi, 3 tane gözleme satış yapan ev, 1 tane de pansiyon bulunmaktadır. Bunların yanı sıra 5-6 tane seyyar yöresel ürün satış yerleri vardır (Resim 1,2).
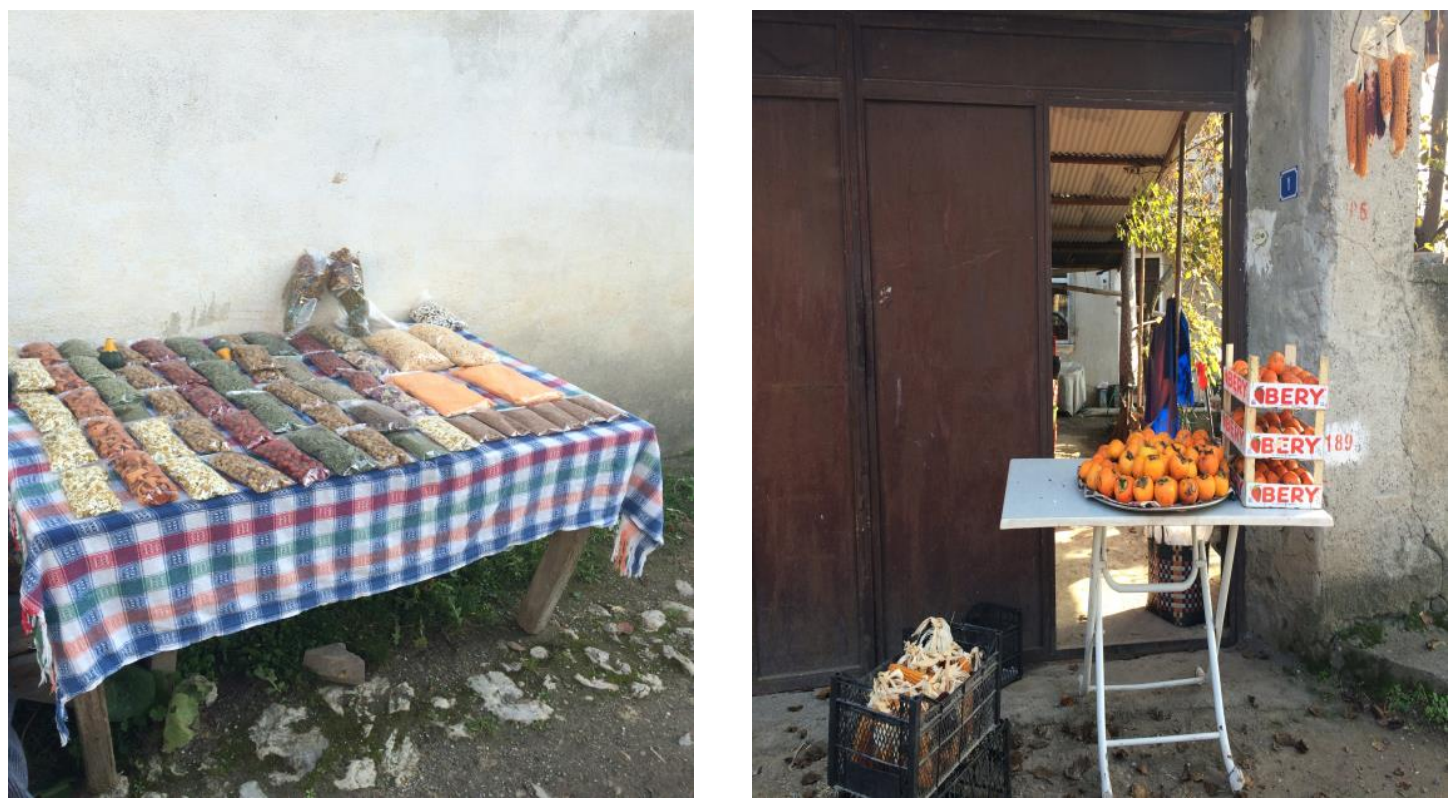

Resim 1,2: Yörük köyünde seyyar satış yapılan yöresel ürün tezgâhları

Köy anıtsal değerleri, tarihi boyutu ve evlerinin özelliklerinin yanında doğal zenginlikleri ile de ender alanlardandir. Bu nedenle yıl boyunca yerli ve yabancı turistler bu yöreyi ziyaret etmektedir. Kültürel turizmin gelişimi köy halkını olumlu ve olumsuz yönde etkilemiştir. Türker v.d. (2011)'in yaptığ 1 araştırmaya göre Yörük köyü halkı turizmin yeni iş imkânları yaratarak istihdamı attırdığına inanmaktadır. Ancak cevaplayıcıların üzerinde önemle durduğu konu turistik gelişmenin köyün ekonomik yaşamı üzerinde beklenilen düzeyde gelişme sağlamadığ́ yönündedir. Köyün genç nüfusunun daha iyi iş imkânları sebebiyle büyük şehirlere ve özellikle İstanbul'a göç ettikleri, böylece de geleneksel yaşam biçiminin tahribata uğradığı ve kısmen de olsa koyun boşaldığı yönünde tespitlerde bulunmaktadırlar. Turizmden beklenen gelecekte köyde daha çok is imkânları yaratarak genç nüfusun köyde kalmasının sağlanmasıdır. Yerli halk turizmin doğal cevre üzerinde olumsuz etki yapmadığına, turistlerin cevre 
kirliliği yaratmadığına inanmaktadırlar. Gelen turistlerin önemli bir kısmını organize turlar oluştursa da koyun fiziksel ve sosyal taşıma kapasite henüz aşılmamıştır. Sosyokültürel yapı ile ilgili olarak köy sakinleri turizmin sosyo-kültürel dokuyu bozmadığına inanmaktadırlar. Bunun yanı sıra yerli halk turizmin turistik üst yapı imkânlarını artırdığına inanmaktadırlar.

Yörük sahip olduğu doğal kaynaklar nedeniyle doğa turistlerinin ilgisini çekebilecek bir potansiyele sahiptir. Köyün sinırlarından geçen Yaci Kanyonu bu kaynakların en önemlileri arasındadır (Resim 3). Sakaralan Köyü'nün Yacı Mahallesi yakınından başlayarak Yörük Köyü sınırlarından geçen Yacı Kanyonu 6 saatte geçilebilmektedir. Kanyonda halihazırda kanyon yürüyüşü yapılmakta, kanyon özellikle yerli ziyaretçilerin ilgisini çekmektedir. Safranbolu ilçesi sınırlarında bulunan üç kanyon; Sırçalı, Düzce ve Yacı kanyonları Konarı köyü civarında birleşmektedir.

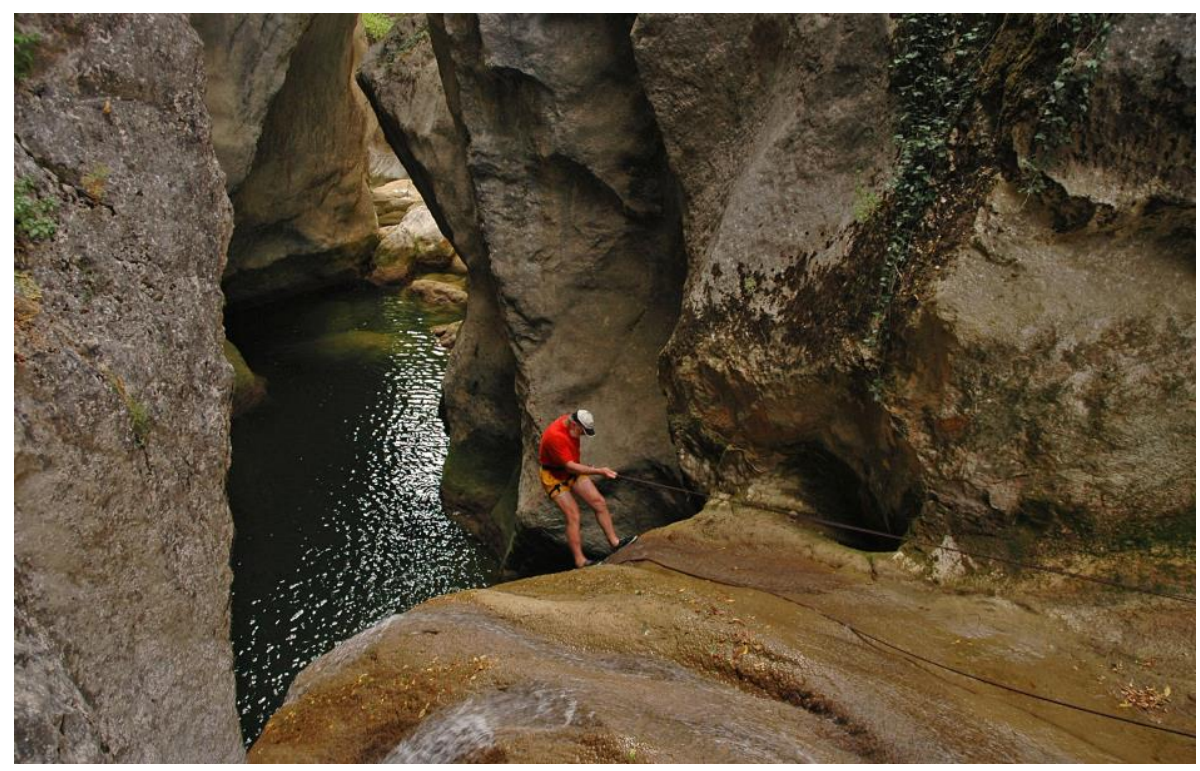

Resim 3: Yaci kanyonu (Türker ve Çetinkaya, 2009).

Köyün güneyinden geçen Araç Çayı Kanoing gibi akarsu aktiviteleri için uygun koşullar sağlamaktadır. Ayrıca çay kenarı boyunca Safranbolu-Toprakcuma Köyü güzergahında trekking ve bisiklet gezileri yapılabilmektedir (Resim 4). Araç Çayı Boyu- Toprakcuma güzergâhı Toprakcuma Köyü'nden başlayıp, Kastamonu - Karabük yolu üzerinde, Safranbolu sapağına yakın bir yerde bulunan tarihi Kavşak Köprüsü'nde sona erer. Köy ve yakın civarında doğa yürüyüşü gerçekleştirilebilecek diğer alanlar şunlardır; Yörük-Köyü-Kepez Dağı, Ulugeçit Köyü - Sakaralan Kanyonu: Parkurun başlangıç noktası Eflani'ye bağlı Ulugeçit Köyü'dür. Buradan başlayan yürüyüş 20 km. sonra Safranbolu'ya bağlı Değirmencik Köyü'ne ulaşmakta ve yürüyüş 2 gün sürmektedir. Köyden sonraki yürüyüş yolu zor bir parkur olup özellikle Yörük Köyü'nün alt kısmında bulunan kanyonun geçilmesi oldukça zordur (Türker v.d., 2011). 


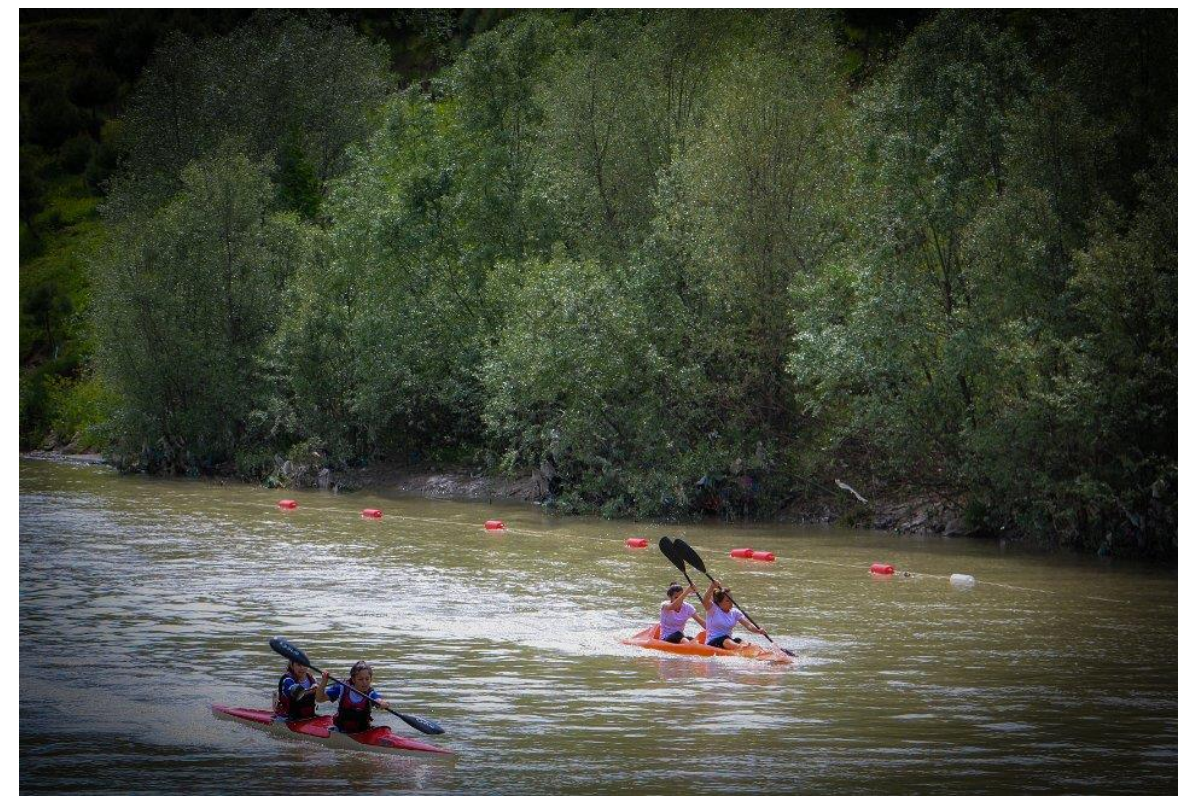

Resim 4: Araç çayı (Anonim 2014)

Köy ayrıca kırsal yaşamın izlenebildiği, geleneksel yaşamın hala önemini koruduğu, Bektaşi yaşamının izlerinin sürülebildiği bir yer olarak ekoturistlerin ilgisini çekebilecek yöresel kültüre sahiptir. Yörük köyünde her yıl düzenli olarak etkinlikler yapılmaktadır. Etkinlikler her yıl ya Ağustos ayının son haftası ya da Eylül ayının ilk haftası yapılmaktadır. Yörük köyü etkinliklerinde geçmişte seymenler eşliğinde gösteriler yapılırken günümüzde kıl çadır kurulup yemek verilmektedir. Etkinlikler, her yıl köyün yerlilerinden birisinin köy ağası seçilmesi ve masrafları karşılaması ile düzenlenmektedir. Köy ağası etkinliğin bütün giderlerini karşılamaktadır (Resim 5).

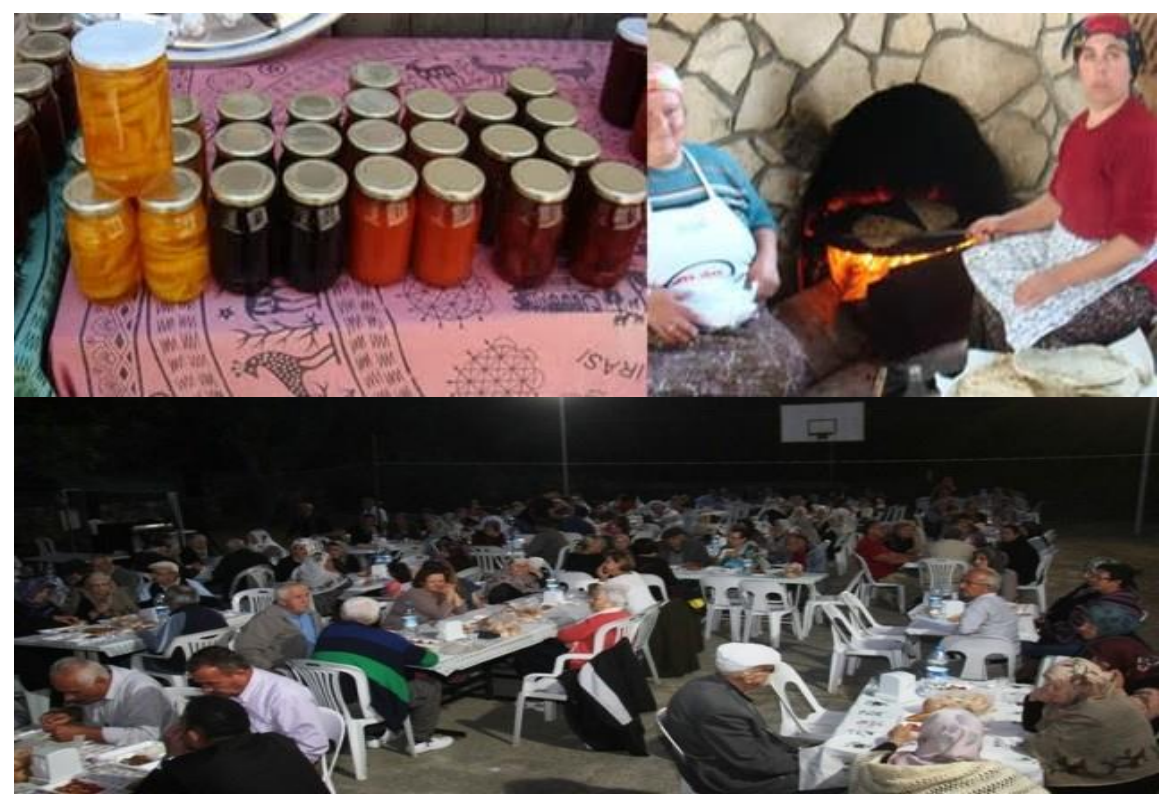

Resim 5: Yörük Köyü Etkinlikleri 


\section{Yöntem}

Çalışma alanında köyün sahip olduğu güçlü ve zayıf yönleri, tehdit ve fırsatları ortaya koyabilmek için R'WOT analizi kullanılmıştır.

\section{R'WOT analizi}

R'WOT analizi (RA) 3 aşamadan oluşmaktadır. Birinci aşama, SWOT analizinin oluşturulmasıdır. Bu aşamada farklı ilgi gruplarından SWOT grupları ve SWOT grubu içindeki SWOT faktörlerinin hangisinin/hangilerinin daha çok tercih edildiğine (önemli olduğu) yönelik karşılaştırma yapmaları istenir. Bu sıralama işlemi, "dokuz dereceli ölçek" kullanılarak yapılmaktadır. Bu ölçekte; 1- zayıf oranda önemli, 3-daha az önemli, 5- orta derecede önemli, 7- daha çok önemli, 9- aşırı derecede önemli olarak kabul edilmektedir. Bunların yanında "2, 4, 6 ve 8 değgrleri" de orta değerler olarak kullanılabilmektedir. İkinci aşamada SWOT gruplarının ve her bir SWOT grubu içindeki SWOT faktörlerinin göreceli öncelik değerleri, her bir SWOT grubuna veya SWOT faktörüne verilen sıraya dayalı olarak hesaplanmaktadır. Örneğin bir (k) karar vericisinin, (j) SWOT grubuna ait SWOT faktörlerine $r_{j k 1}, r_{j k 2}, \ldots, r_{j k m}$ şeklinde bir sıralama verdiği kabul edilsin. Buna göre (j) SWOT grubundaki (i) SWOT faktörünün göreceli öncelik değeri olan $X_{j i}$ değeri, RA kullanılarak, aşağıdaki şekilde hesaplanabilmektedir:

$$
X_{\mathrm{ji}}=\frac{\sum_{\mathrm{k}} \mathrm{r}_{\mathrm{jki}}}{\sum_{\mathrm{i}} \sum_{\mathrm{k}} \mathrm{r}_{\mathrm{jki}}} \quad(\mathrm{i}=1,2, \ldots, \mathrm{m})
$$

Üçüncü aşamada ise Doğrusal Kombinasyon Analizi, her bir SWOT faktörünün göreceli öncelik değerleri ile bu faktörün bağlı olduğu SWOT grubunun öncelik değeri çarpılmaktadır. Böylece, matematiksel olarak "doğrusal kombinasyon" işlemi gerçekleştirilmekte SWOT faktörlerinin göreceli öncelik değerleri aynı ölçeğe konularak, birbirleri ile karşılaştırılabilir hale gelmektedir (Yılmaz, 2006). Bu işlem, dört SWOT grubunun her birisi için ayrı ayrı gerçekleştirilmektedir. Bu teknikte kullanılan doğrusal eşitlik, aşağıdaki şekilde gösterilebilmektedir:

$$
\mathrm{P}_{\mathrm{ji}}=\mathrm{W}_{\mathrm{ji}} \quad \mathrm{X}_{\mathrm{ji}}
$$

Burada, $P_{\mathrm{ji}}$ ( (j) SWOT grubundaki (i) SWOT faktörünün nihai öncelik değeri, $\mathrm{W}_{\mathrm{ji}}$ : (i) SWOT faktörünün dahil olduğu (j) SWOT grubunun göreceli (aynı zamanda nihai) öncelik değeri, $X_{j i:}$ (j) SWOT grubundaki (i) SWOT faktörünün göreceli öncelik değeri olmaktadır (Yılmaz, 2006).

SWOT analizi; stratejik plan geliştirilmesi, sorun tanımlama ve çözüm oluşturulması aşamalarında, nicel verilerin yetersiz, bilgilerin kişilerin belleklerinde olduğu durumların analizinde kullanılmaktadır. Swot analizi, eğer doğru şekilde kullanılırsa, stratejilerin belirlenmesinde uygun bir araçtır. Buna karşın SWOT çözümlemeleri stratejik karar verme problemini kapsamlı bir şekilde ele alma olanağı vermez. Zira bu çözümlemelerde Üstünlükler, Zayıflıklar, Fırsatlar ve Tehditler gruplarının her birindeki faktörler sıralanmakta, ancak bu grupların öncelik sıralaması 
ortaya konamamaktadır. Bunun yanında her bir gruptaki faktörlerin öncelikleri de sayısal olarak belirlenememektedir. SWOT çözümlemelerinin belirtilen eksiklerinin üstesinden gelmek üzere, Yılmaz (2006) tarafından geliştirilmiş ve "R'WOT Tekniği" olarak adlandırılmış bir melez teknik yaklaşımı bulunmaktadır. Bu yaklaşımda bir ağırlıklandırma tekniği olan "Sıralama Tekniği" ve çok kriterli karar verme tekniklerinden birisi olan "Doğrusal Kombinasyon Tekniği”, SWOT çözümlemeleri ile bütünleştirilmiştir. Böylece SWOT grupları ve her bir SWOT grubu içerisindeki SWOT faktörlerine yönelik öncelikler ölçülebilir hale getirilmiş ve sayısal olarak belirlenmiştir (Gürbüz ve Öztürk, 2013).

Safranbolu Yörük köyü ve yakın çevresinde ekoturizm potansiyelinin R'WOT analizi ile değerlendirilmesine yönelik bu çalışmada, bölgenin "Güçlü yönleri", "Zayıf yönleri" "Fırsatlar" ve "Tehditlerini" belirlemek için birbirinden bağımsız olarak SWOT analizi çalışması gerçekleştirilmiştir. Çalışmada, yerel yönetim (5), yöre halkı temsilcisi (10) ve uzman gruplarından (5) oluşan toplam 20 katılımcı ile görüşülmüştür.

- Araştırma kapsamında anketi yanıtlayan katılımcıların \% 80'ini temsil eden 16 kişinin erkek, \% 20 ile 4 kişinin ise kadın olduğu görülmektedir. Katılımcıların $\%$ 65'i evlidir.

- Katılımciların \% 55'i kamu'da görev yapmakta iken, \% 20'si özel sektörde çalışmaktadırlar.

- Katılımcıların yaş aralığı 24 ile 59'dur.

- Araştırmaya katılan yöre halkından (10); 2 kişi 1-5 yıl, 4 kişi 5-10 yıl, geri kalanlar ise 15 yıldan uzun süredir köyde yaşamaktadırlar.

- Katılımcıların eğitim düzeyi incelendiğinde ise \% 15'i ilköğretim, \% 20'si lise, \% 30'u üniversite ve \% 35'i yüksek lisans/doktora eğitimi almışlardır.

$\mathrm{Bu}$ uygulama sonucunda, Yörük Köyü'nün mevcut durumunu değerlendirmede kullanılacak SWOT faktörleri aşağıda yer aldığı şekilde belirlenmiştir.

\section{Güçlü Yönleri}

1. UNESCO Dünya Miras Kenti Safranbolu' ya bağlı bir köy oluşu, (G1)

2. Yöresel adetlerin, folklorik değerlerin çeşitliliği ve halen yaşatılması, yöresel ürün satışlarının yapılıyor olması (havlu, sofra bezi, sabun türleri, minyatür Safranbolu evleri) (G2)

3. Ulaşım kolaylığı bulunması, (G3)

4. Doğal tarihi ve kültürel değerlere sahip olması, (G4)

5. Köyün Kültür ve Turizm Bakanlığı tarafından koruma altına alınmış olması, (G5)

6. İklimin güzel olması (Yazları sıcak kışları ılıman). (G6) 


\section{Zayıf Yönler}

1. Genç nüfusun eksikliği, (Z1)

2. Yerel halkın pansiyonculuğa sıcak bakmaması, (Z2)

3. Nitelikli işgücünün yeterli olmaması, (Z3)

4. Köy evlerinin restorasyonunun yavaş işleyişi, $(\mathrm{Z} 4)$

5. Köyün geleneksel mimarisi ile uyumsuz yapılaşmaların varlığı. (Z5)

\section{Firsatlar}

1. Büyük kentlere yakın olması ve günübirlik turlar için uygun olması, (F1)

2. Ekoturizme ve doğa sporlarına ilginin artması (Köy hayatı, Orman yürüyüşü, Çadır hayatı, Kanyon gezintileri...) (F2)

3. Bartın, Amasra ve İnkumu gibi tatil yörelere yakınlığı. (F3)

\section{Tehditler}

1. Doğa sporlarına ilişkin hiçbir alt yapı çalışmasının bulunmaması, (T1)

2. Turist yoğunluğunun geleneksel doku üzerinde oluşturabileceği baskılar, (T2)

3. Kardemir' den kaynaklanan çevre kirliliği, (T3)

4. Köyde yaşayanların büyükşehirlere göç etmesi. (T4)

\section{Bulgular ve Tartışma}

Çalışmada, yerel yönetim (5), yöre halkı (10) ve uzman gruplarından (5) oluşan toplam 20 katılımcı ile görüşülmüş, katılımcıların eşit ağırlığa sahip olduğu varsayılarak, katılımcıların güçlü ve zayıf yönlere, tehdit ve fırsatlara yönelik olarak verdikleri kararlar ve öncelik değerlerinin aritmetik ortalamaları alınmış ve sonuçları Tablo 1'de verilmiştir. 
Tablo 1: Katılımcıların R'WOT Analizi Sonuçları

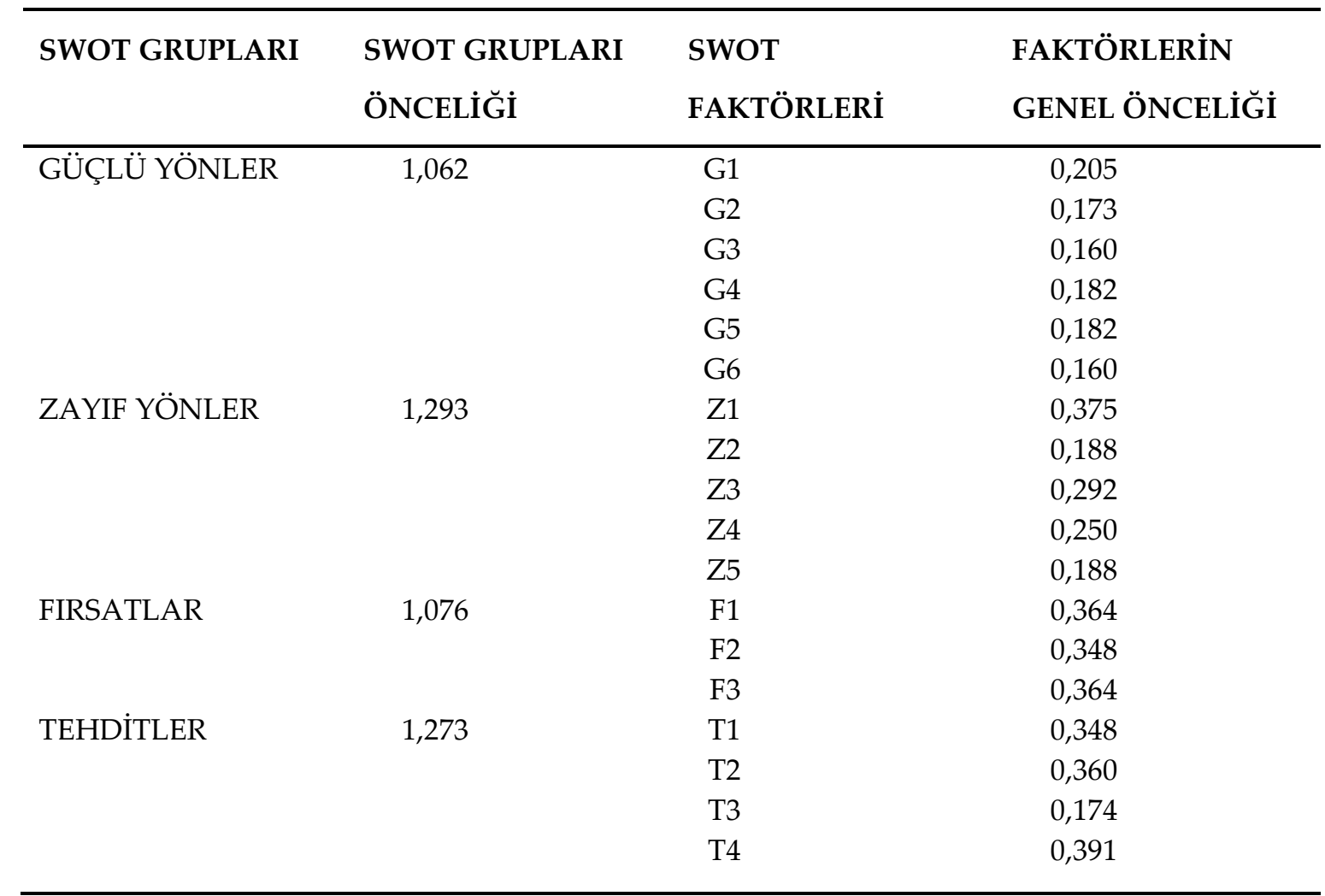

Her bir katılımcı grup için de SWOT grupları ve faktörlerinin öncelik değerleri ayrıca belirlenmiştir. Tablo 1'e göre SWOT gruplarından en öncelikli 1,293 öncelik değeri ile "zayıf yönler", 1,273 öncelik değeri ile "tehditler" grubudur. Bunu sirasıyla 1,076 öncelik değeri ile "fırsatlar" ve 1,062 öncelik değeri ile "güçlü yönler" grubu izlemektedir.

- Güçlü yönler grubunda 0,205 öncelik değeri ile " UNESCO Dünya Miras Kenti Safranbolu' ya bağlı bir köy oluşu" faktörü ile en yüksek önceliğe sahiptir.

- Zayıf yönler grubunda 0,375 öncelik değeri ile " Genç nüfusun eksikliği" faktörü ile yüksek önceliğe sahiptir.

- Firsatlar grubunda 0,364 öncelik değeri ile " Büyük kentlere yakın olması ve bununla birlikte günübirlik turlar için uygun olması" ve " Bartın, Amasra ve İnkumu gibi tatil yörelere yakınlığı" faktörü ile yüksek önceliğe sahiptir.

- Tehditler grubunda 0,391 öncelik değeri ile " Köyde yaşayanların büyük şehirlere göç etmesi" faktörü ile yüksek önceliğe sahiptir.

Tüm gruplar için, " UNESCO Dünya Miras Kenti Safranbolu' ya bağlı bir köy oluşu" güçlü yön faktör olarak değerlendirilmiştir. (Bkz. Tablo 2) "Genç nüfusun eksikliğgi" yüksek öncelikli zayıf yön faktör olarak değerlendirilmiştir. Bu faktörü yerel yönetimler ve uzman grupları desteklemektedir. Ancak yöre halkına göre ise "Köy evlerinin restorasyonunun yavaş işleyişi" daha yüksek öncelikli zayıf yön olarak belirlemişlerdir. 
Tablo 2: Katılımcı grupların SWOT gruplarına verdikleri öncelikli değer sonuçları

\begin{tabular}{llll}
\hline SWOT Grupları & Yerel Yönetim & Yöre Halkı & Uzmanlar \\
\hline Güçlü Yönler & $\begin{array}{l}\text { UNESCO Dünya Miras Kenti } \\
\text { Safranbolu' ya bağlı bir köy } \\
\text { oluşu }\end{array}$ & $\begin{array}{l}\text { UNESCO Dünya Miras Kenti } \\
\text { Safranbolu' ya bağlı bir köy } \\
\text { oluşu }\end{array}$ & $\begin{array}{l}\text { UNESCO Dünya Miras Kenti } \\
\text { Safranbolu' ya bağlı bir köy } \\
\text { oluşu }\end{array}$ \\
\hline Zayıf Yönler & Genç nüfusun eksikliği & $\begin{array}{l}\text { Köy evlerinin restorasyonunun } \\
\text { yavaş işleyişi }\end{array}$ & Genç nüfusun eksikliği \\
Fırsatlar & $\begin{array}{l}\text { Bartın, Amasra ve İnkumu gibi } \\
\text { tatil yörelere yakınlı̆ıı }\end{array}$ & $\begin{array}{l}\text { Büyük kentlere yakın olması ve } \\
\text { günübirlik turlar için uygun } \\
\text { olması }\end{array}$ & $\begin{array}{l}\text { Ekoturizme ve doğa sporlarına } \\
\text { ilginin artması (Köy hayatı, } \\
\text { Orman yürüyüşü, Çadır hayatı, } \\
\text { Kanyon gezintileri...) }\end{array}$ \\
\hline Tehditler & $\begin{array}{l}\text { Köyde yaşayanların } \\
\text { büyükşehirlere göç etmesi }\end{array}$ & $\begin{array}{l}\text { Turist yoğunluğunun } \\
\text { geleneksel doku üzerinde } \\
\text { oluşturabileceği baskılar }\end{array}$ & $\begin{array}{l}\text { Köyde yaşayanların } \\
\text { büyükşehirlere göç etmesi }\end{array}$ \\
\hline
\end{tabular}

Tüm gruplar genel olarak “Büyük kentlere yakın olması ve günübirlik turlar için uygun olması" faktörünü en yüksek öncelikli firsat olarak belirlemişlerdir. Yöre halkı da bu faktörü en önemli fırsat olarak değerlendirmişlerdir. Bununla birlikte, yerel yönetimlere göre en yüksek öncelikli fırsat, köyün “Bartın, Amasra ve İnkumu gibi tatil yörelere yakın olması", uzman grubuna göre ise "Ekoturizme ve doğa sporlarına olan ilginin artması"dır.

Yerel halk için "Turist yoğunluğunun geleneksel doku üzerinde oluşturabileceği baskılar" en yüksek öncelikli tehdidi oluştururken, uzman ve yerel yönetim grupları için "Köyde yaşayanların büyükşehirlere göç etmesi" yüksek öncelikli tehdit olarak belirlenmiştir.

\section{Sonuç ve Öneriler}

Yörük köyü, sahip olduğu değerler ile turizm açısında yüksek bir potansiyele sahiptir. Bu sebeple gerek köyün gerekse yakın çevresinin ekoturizm potansiyeli R'WOT analizi ile değerlendirilmeye çalışılmıştır. Çalışmada, yerel yönetim (5), yöre halkı temsilcisi (10) ve uzman gruplarından (5) oluşan toplam 20 katılımcı ile görüşülmüş, tüm katılımcıların eşit ağırlığa sahip olduğu varsayılarak güçlü ve zayıf yönlere, tehdit ve fırsatlara verdikleri hüküm ve önceliklerinin aritmetik ortalama değerleri alınarak ortaya çıkarılan öncelikli konular sırasıyla aşağıda verilmiştir:

\section{Değerlendirilmesi gereken öncelikler:}

- Büyük kentlere yakın olması ve bununla birlikte günübirlik turlar için uygun olması (0.364),

- Bartın, Amasra ve İnkumu gibi tatil yörelere yakınlığı (0.364),

- Ekoturizme ve doğa sporlarına ilginin artması (Köy hayatı, Orman yürüyüşü, Çadır hayatı, Kanyon gezintileri...) (0.348),

- UNESCO Dünya Miras Kenti Safranbolu' ya bağlı bir köy oluşu (0.205), 
- Köyün Kültür ve Turizm Bakanlığı tarafından koruma altına alınmış olması, (0.182),

- Doğal tarihi ve kültürel değerlere sahip olması (0.182),

- Yöresel adetlerin, folklorik değerlerin çeşitliliği ve halen yaşatılması, yöresel ürün satışlarının yapılıyor olması (havlu, sofra bezi, sabun türleri, minyatür Safranbolu evleri) (0.173),

- İklimin güzel olması (0.160), değerlendirilmesi gereken önemli potansiyellerdir.

\section{Önlem alınması gereken öncelikler:}

- Köyde yaşayanların büyükşehirlere göç etmesi (0.391),

- Genç nüfusun eksikliği (0.375),

- Turist yoğunluğunun geleneksel doku üzerinde oluşturabileceği baskılar, (0.360),

- Doğa sporlarına ilişkin hiçbir alt yapı çalışmasının bulunmaması (0.348),

- Nitelikli işgücünün yeterli olmaması (0.292),

- Köy evlerinin restorasyonunun yavaş işleyişi (0.250),

- Yerel halkın pansiyonculuğa sıcak bakmaması (0.188),

- Köyün geleneksel mimarisi ile uyumsuz yapılaşmaların varlığı (0.188),

- Kardemir' den kaynaklanan çevre kirliliği (0.174).

Önemli sorunlar olmaktadır.

Tüm değerler göz önünde tutulduğunda SWOT grupları değerlerinin hatta birçok faktör değerlerinin birbirine yakın olduğu görülmektedir. Günümüzde turist profili Dünya genelinde; alışılmış turizm merkezlerinden uzaklaşarak, doğayla baş başa yaşama olanağı tanıyan alternatif turizm alanlarına doğru yönelmektedir. Bu kapsamda, doğa severlere, macera arayanlara, nostalji yaşamak isteyenlere, farklı kültürleri tanımak isteyenlere alternatif turizm merkezleri olarak kırsal alanlar (köyler, çiftlikler vb.) önerilmektedir.

\section{Kaynakça}

Altan Ş. (2006). Türkiye'de Ekoturizm Uygulamaları ve Ekonomiye Katkıları (Basılmamış Yüksek Lisans Tezi). Niğde: Niğde Üniversitesi. Sosyal Bilimler Enstitüsü,

Anonim (2014). Karabük Üniversitesi 16.12.2014 tarihinde http://www.karabuk.edu.tr/etk_detail.asp?etkinlikID=1409. adresinden erişildi.

Benzer N. A. (2006). Bolu-Göynük ve Yakın Çevresi Doğal ve Kültürel Kaynaklarının Ekoturizm Açısından Değerlendirilmesi (Basılmamış Doktora Tezi). Ankara: Ankara Üniversitesi, Fen Bilimleri Enstitüsü. 
Cengiz T. (2003). Peyzaj Değerlerinin Korunmasına Yönelik Kırsal Kalkınma Modeli Üzerine Bir Araştırma: Seben İlçesi (Bolu) Alpağut Köyü Örneği (Basılmamış Doktora Tezi). Ankara: Ankara Üniversitesi. Fen Bilimleri Enstitüsü.

Demirarslan D. (2011). Eski Bir Bektaşi Yerleşimi: Yörük Köyü'nde Evler Ve Odanın Oluşumu. Türk Kültürü ve Hacı Bektaş Veli Araştırma Dergisi, Sayı 58,Kocaeli.

Gürbüz F. ve Öztürk E. (2013). Bir Tekstil Sanayi Sevkiyat Bölümünde R'WOT Analizi Uygulanması, Erciyes Üniversitesi Fen Bilimleri Enstitüsü Dergisi, 29(3):247-253

Kara T. (2005). Safranbolu Yörükköyü Köyümüzde Geleneksel Yaşam, Örf ve Adetlerimiz. Grafiker Ofset Ltd. Şti., 1. Baskı, Ankara.

Kılıç F. ve Kökel C. (2006). Bektaşilik Üzerine Değerlendirmeler ve Çalçakırlar Köyü Örneğinde Bektaşi Kültürü. Türk Kültürü ve Hacı Bektaş Veli Araştırma Dergisi, Sayı 40, Ankara.

Kiper T. (2006). Safranbolu Yörük köyü Peyzaj Potansiyelinin Kırsal Turizm Açısından Değerlendirilmesi (Basılmamış Doktora Tezi). Ankara: Ankara Üniversitesi. Fen Bilimleri Enstitüsü.

Öztürk M. (1996). Bektaşilik. Kültür Bakanlığı Yayınları, c. I, Ankara.

Pedersen A. (2002). ManagingTourism at World Heritage Sites: a Practical Manual for World Heritage Site Managers. Published by UNESCO World Heritage Centre, Paris.

TÜIKK, 2012. Adrese Dayalı Nüfus Kayıt Sistemi Nüfus Sayımı, Türkiye İstatistik Kurumu, Karabük.

Turoğlu H. ve Özdemir H. (2005). Bartın İlinin Ekoturizm Potansiyelinin Belirlenmesi. Doğu Coğrafya Dergisi, Sayı 13, Konya.

Turker, N. Yıldırım, M. ve Gül, T. (2013). Bektashi-Yoruk Culture within the Context of Culture Tourism and Tourism Perceptions of the Villagers, I. Uluslararası Karadeniz Kültür Kongresi Bildiri Kitabı. Karabük Üniversitesi yayını, 617-628.

Türker N. (2013). Batı Karadeniz Bölümü Ekoturizm Kaynaklarının Değerlendirilmesi ve Bir Ekoturizm Rotası Önerisi. The Journal of Academic Social ScienceStudies, International Journal of Social Science, Volume 6, Issue 4, s. 1093-1128.

Türker N., Çetinkaya, A., Barutçu, H. ve Emir, G. (2011). Zonguldak, Karabük ve Bartın Illeri Turizm Sektör Analizi. Turmatsan Matbaacılık, İstanbul.

Türker N. ve Çetinkaya A. (2009). Batı Karadeniz Bölümü Ekoturizm Potansiyeli, ISBN: 978-60589395-0-9, Ankara: Detay Yayıncilık.

Yılmaz E. (2006). R'WOT Tekniğgi: Arıcılık Sektöründe Katılımcı Yaklaşım ile Örnek Bir Uygulaması, (DOA Dergisi, T.C. Çevre ve Orman Bakanlığı, Doğu Akdeniz Ormancılık Araştırma Müdürlüğü, 40 (6): 93, Tarsus. 